\title{
The provision of water infrastructure in Aboriginal communities in South Australia
}

\author{
Eileen Willis, Meryl Pearce, Carmel McCarthy, Fiona Ryan and Ben Wadham
}

The provision of water supplies to Aboriginal people in South Australia, particularly to communities covered under the Commonwealth-State (South Australia) Bilateral Agreement ${ }^{1}$ is considered world class in terms of the suitability of the technology to the remoteness of many of the communities and the harsh arid environment. This article explores the history of domestic water supplies to these Aboriginal communities. The article begins with a brief outline of pre-contact Aboriginal technologies for the maintenance of water supplies and reflects on the continuity of these approaches through the early years of pastoralist and missionary settlement. This is followed by a description of the services offered by the state and federal governments since the late 1970s to the present. The provision of these services can be divided into three distinct phases: the initial installation of state government infrastructure beginning in 1979 following the transfer from mission to government control; the appropriate technology phase from 1989 to 2000; and the mainstreaming phase from 2000 to 2009. The provision of essential services to any population is influenced by various political events. In the case of water supplies to Aboriginal communities three events are examined: the impact of the National Competition Policy on the work of the Essential Services Team, the Department of State Aboriginal Affairs (DOSAA) Strategic Plan on water supplies in Aboriginal communities in 2000, and planning for the National Water Initiative in 2005.

\section{Methodology}

Data for this paper came from two research projects carried out under the auspices of the Aboriginal Affairs and Reconciliation Division (AARD) of the Department of Premier and Cabinet (South Australia). ${ }^{2}$ In 2003 the research team provided AARD with a report on Aboriginal community residents' views of their domestic water supply and, from 2005 to 2007, the implications of the National Water Initiative on two communities under the CommonwealthState Bilateral Agreement and two communities outside the Agreement were

1 Indigenous Studies Program, Agreements, Treaties and Negotiated Settlements Project 2006.

2 Both projects were funded by the Aboriginal Affairs and Reconciliation Division of Premier and Cabinet (AARD). Project 1 was also funded by Veolia Water. The second project was funded by AARD, the Commonwealth Department of Families, Community Services and Indigenous Affairs, United Water, the CRC in Aboriginal Health and the Desert Knowledge CRC. 
examined. ${ }^{3}$ Data were gathered on the history of domestic water supply in ten of the 18 communities covered under the Agreement. Further data were collected through focus group interviews with Aboriginal people in ten communities, and interviews with personnel from the Department of State Aboriginal Affairs (DOSAA), SA Water, the Aboriginal and Torres Strait Islander Commission (ATSIC), the Commonwealth Department of Families and Community Services (FACS) and the South Australian Government Department of Human Services. ${ }^{4}$ The insights of these staff provided a framework for examining some of the major developments over a 30-year period from the late 1970s to the present.

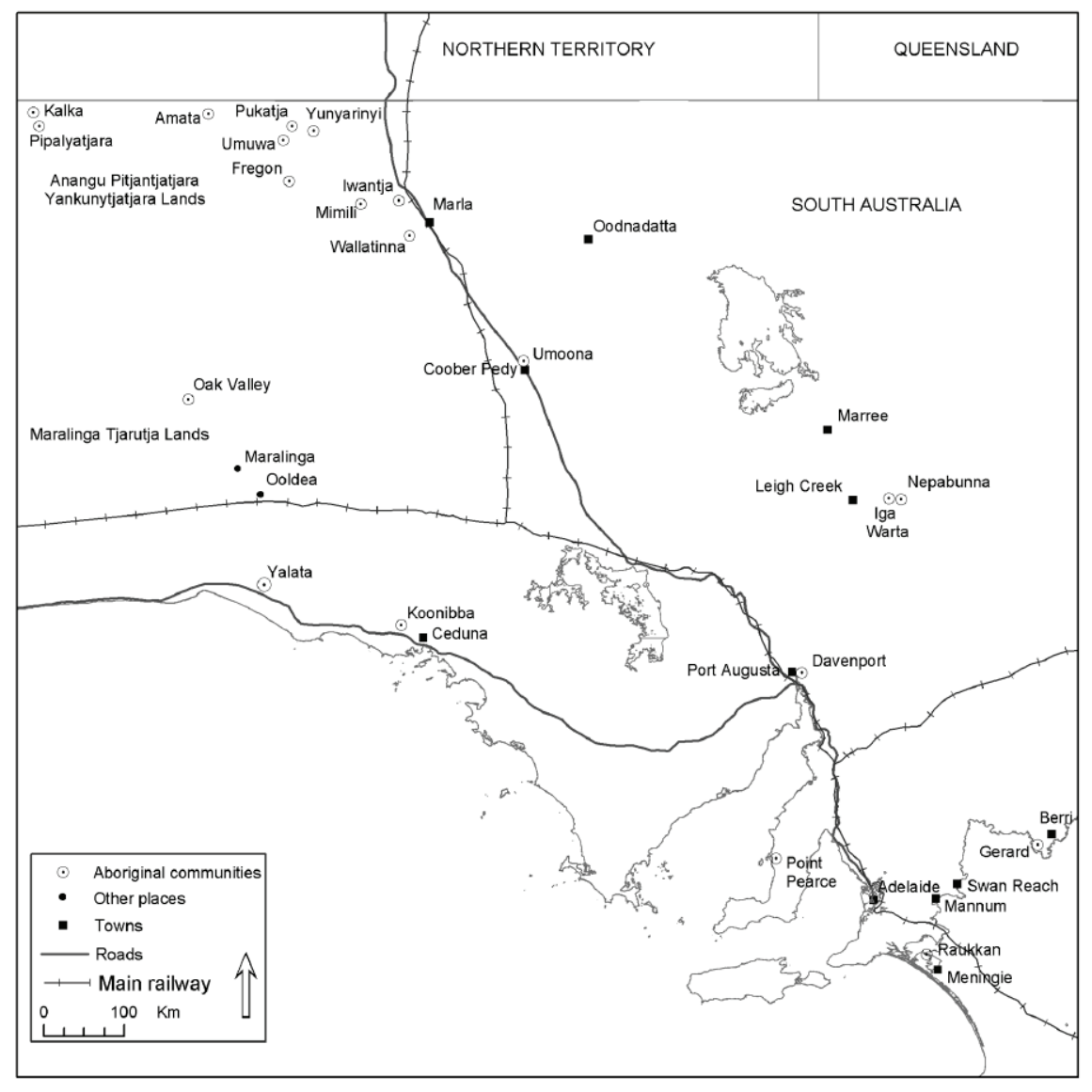

Fig 1. Location of Aboriginal communities in South Australia.

3 Pearce et al 2008; Willis et al 2004.

4 Department of State Aboriginal Affairs and Reconciliation (DOSAA) became Department of Aboriginal Affairs and Reconciliation (DAARE) in 2003, and Aboriginal Affairs and Reconciliation Division of Premier and Cabinet (AARD) in 2005. The Commonwealth Department of Family and Community Services (FACS) became Commonwealth Department of Families, Housing, Community Services and Indigenous Affairs (FaHCSIA) in 2006. The Department of Human Services (DHS) became the Department of Health in 2004. 
The majority of Aboriginal communities that formed part of this study are in arid to semi arid regions with mean annual rainfall around 250 millimetres or less. In most regions the rainfall is highly variable and characterised by droughts of varying duration. Over most of outback South Australia summer temperatures are high with averages above $30^{\circ}$ to $40^{\circ} \mathrm{C}$, and winter temperatures ranging from $20^{\circ} \mathrm{C}$ to below freezing. ${ }^{5}$ Water supplies in these communities come from three sources: the Murray River through SA Water, groundwater within the communities or supplied through local government, and rainwater harvesting (RWH) through the provision of household water tanks and other larger scale catchment infrastructure. In a small number of communities the groundwater supply is not sustainable over the next 20 years, while river and RWH supplies are subject to the impact of drought. ${ }^{6}$

\section{Water supply in Aboriginal communities prior to government intervention}

Prior to European settlement and for the first 150 years of colonisation the irregular rainfall, drought and scarcity of permanent water supplies in South Australia meant that Aboriginal people such as the Kokatha, Pitjantjatjara, Mirning, Wirangu, Adnyamathanha and Pangkala living in remote outback areas depended on their traditional knowledge of water sources and skill in accessing supplies. Details of this knowledge have been recorded by a number of historians and anthropologists who point to Aboriginal people's depth of memory of water sources, and technologies in accessing and conserving water. For example, Bayley records that knowledge of the type and location of water sources was passed on through oral instruction and the use of stylised maps; this knowledge extended even to the approximate volume of water held at the source. Adults memorised this knowledge passing it on to children as they visited these water sources in the cyclic journeys that governed their lives. ${ }^{7}$ Similar reports are noted by Tindale for the Great Sandy Desert; he talks of the use of stylised maps using spirals to identify the location of pools and soakage-wells. ${ }^{8}$

Aboriginal people's knowledge of water sources also came from observation of the behaviour of animal and birds. Magarey notes the importance of animals and birds as guides to water sources for Aboriginal people. Birds such as the zebra finch, the striated pardalote and the red browed pardalote are excellent water finders leading people to uncover wells, rock holes and springs. ${ }^{9}$ Bayley also cites accounts of Aboriginal people extracting water from desert oaks,

5 Bureau of Meteorology 2008.

6 Willis et al 2004.

7 Bayley 1999.

8 Tindale 1974.

9 Magarey 1899 as cited in Bayley 1999. 
bloodwoods and cork trees using grasses joined together. Water was also obtained from the roots of trees such as red mallee, desert kurrajong, desert oak and Grevillea nematophylla. ${ }^{10}$

Traditionally Aboriginal people employed a range of human-made technologies in accessing water. This included enlarging rock holes and in some cases chipping grooves in the rocky slopes surrounding them to divert more water into the holes. ${ }^{11}$ Often rock holes were covered with branches or flat slabs of rock to reduce evaporation and stop animals gaining access. Other examples of the constructed water sources in desert regions included impoundments or dams made from clay with wooden shovels. One described by the explorer Giles in 1889 in the far western regions of South Australia had clay dug out from a dam approximately 18 metres long and 1.5 metres deep. ${ }^{12}$ Another described by Basedow involved a method of extracting water using a very small circular opening on the surface of the rock hole leading to a reservoir of water below. In such cases:

A bundle of grass or bush was tightly wound around the bottom end of a rod, about five feet long. The rod was inserted in the hole, the bundle foremost and tightly fitting into the passage, and slowly pushed inward through its whole length. After a short time it is rapidly withdrawn; the water that had collected in front of the 'piston' being thereby forcibly ejected. This water was then collected inside the walls of a small enclosure built with clay outside the entrance. ${ }^{13}$

Aboriginal people were able to survive in small groups using these existing water sources, but the gradual move by pastoralists and cameleers into the remote regions of South Australia during the early colonial period resulted in the need to find larger quantities and regular water supplies; the source of which often owed much to Aboriginal knowledge. For example, Anderson reports that the first permanent water supply at Port Augusta (Fig 1) was discovered by Paul Michen, the protector of Aborigines with assistance from the local Nukunu people. ${ }^{14}$ Likewise, the presence of water determined where missions were established. The current sites for Koonibba east of Ceduna (Fig 1) and Nepabunna in the Flinders Ranges were motivated by the presence of small creeks and springs which functioned as the major water supplies for these communities until the 1970s and played a significant role in the water conservation ethic developed by Aboriginal people as they moved to fixed settlement. The Adnyamathanha people at Nepabunna speak fondly and with wry humour of the missionaries' endeavours to conserve water even to the point of coming uninvited into people's houses to turn off dripping taps. ${ }^{15}$

10 Bayley 1999.

11 Bayley 1999.

12 Giles 1889.

13 Basedow 1906: 5.

14 Anderson 1988: 50.

15 Willis et al 2004. 
Knowledge of Aboriginal water sites also played a major role in development in remote regions. The establishment of the railway siding at Ooldea (Fig 1) owed much to the soak nearby. This central meeting place for a number of Aboriginal groups provided up to 320,000 litres of water per week during the major construction period of the railway service around $1912 .{ }^{16}$ Sustainability and conservation of water remains a paramount concern for Aboriginal people who continue to manage these traditional water sources, rivers, rock holes and water holes today mainly through Natural Resource Management (NRM) projects, and previously through the Community Development Employment Programs (CDEP), and cultural tourism related endeavours. Water conservation occurs also as a result of cultural obligations and is strongly linked to the Dreaming both as providing markers or boundary points for ownership of country, and as a basis for 'explaining' country. The most obvious example of this is the Rainbow Serpent. ${ }^{17}$ Understanding of the importance of water goes beyond scientifically motivated environmental considerations of sustainability to a strong belief in the metaphysical meaning of water; summed up in the belief that if waterholes 'no longer hold water for Anangu the country dies' ${ }^{18}$

\section{State government intervention from 1979 to 2007}

The initial foray of the South Australian State Government into supplying domestic water and other essential services to remote Aboriginal communities began by chance but moved quickly from an ad hoc response to a planned program characterised by standardised equipment highly suitable for the arid environment and remoteness from mainstream services. Significant influences were the various reports on the health of Aboriginal people in remote regions during the 1960s and 1970s, but also the gradual up-take by the state government of their responsibilities to the various communities following the national move for churches to hand over responsibility of missions to the local Aboriginal people from the 1950s onwards. This move, accelerated by the 1967 referendum, resulted in the gradual formation within state governments of dedicated units with responsibility for remote community infrastructure. ${ }^{19}$ While it should not be presumed that state governments had no engagement in Aboriginal communities, especially education and the subsidising of health services, prior to 1967, much of the day-to-day infrastructure was funded or handled by missionary societies. In South Australia, government involvement in providing Aboriginal communities with water infrastructure can be divided into three phases: the first period extends from 1979 to 1989 and coincides with the transfer of missions to local Aboriginal people under policies of self-determination and the signing of the first State-Commonwealth Bilateral Agreement dedicating funds for community infrastructure; the second period from 1990 to 2000 was a time of consolidation and standardisation of infrastructure; while the final

16 Mattingley and Hampton 1988.

17 Toussaint et al 2005.

18 Aboriginal Lands Integrated Natural Resource Management Group 2003: 64.

19 Willis et al 2004. 
period, 2000 to the present, represents a move towards mainstreaming in line with both federal government policy for Aboriginal communities following the disestablishment of the Aboriginal and Torres Strait Islander Commission. This move is consistent with risk management practice for water supplies across Australia and is in line with the National Water Initiative ${ }^{20}$ and Australian Quality Drinking Water Guidelines. ${ }^{21}$

\section{The initial phase from 1979 to 1989: getting started}

The major catalyst for state government engagement in the provision of essential services on Aboriginal communities was the 1976 House of Representatives Standing Committee on Aboriginal Affairs, Review into Aboriginal Health. ${ }^{22}$ The findings from this review pointed to the need for improved public health as a major way of confronting Aboriginal health issues. The Commonwealth government committed $\$ 50$ million over five years to be spent on improvements to essential services in Aboriginal communities across Australia. Senior staff from the Commonwealth Department of Aboriginal Affairs in the regional office in Alice Springs approached the South Australian Government Outback Services to begin the task of providing appropriate water infrastructure to communities on what would eventually become known as the Anangu Pitjantjatjara Yankuntjatjara Lands (APY) Lands (Fig 1).

Outback Services, a small division within the SA Public Buildings Department, already had a presence on the APY Lands managing government assets and infrastructure connected with state education, government housing and law enforcement. The APY lands cover an area of approximately 10 per cent of the state and were formerly part of the North West Aboriginal Reserve. The Pitjantjatjara Land Rights Act 1981 (SA) was proclaimed in 1981. Initially introduced by the Dunstan Labor Government in 1978 following lobbying by the Anangu people, it took the Tonkin Liberal Government to finally pass it in 1981. The Act provides the Pitjantjatjara and Yankuntjatjara people with ownership and title over their land beyond the Aboriginal Land Rights (Northern Territory) Act 1976 (Cth) used in the Northern Territory. The significance of the Act was that it represented the first state government recognition of land ownership and gave total ownership of land to the Anangu people. ${ }^{23}$

An assessment and recommendation for improvements of the essential services infrastructure in Aboriginal communities in the then APY Lands was undertaken by the Outback Services Division at this time as part of the state government's response to the federal review on Aboriginal health. In 1985 Outback Services was renamed the Aboriginal Works Division, still within the Public Buildings Department, and then within Department of Housing and Construction (known as SACON or South Australian Construction) with the

20 Council of Australian Governments 2004.

21 National Health and Medical Research Council 1996.

22 Australian Government and House of Representatives 1979.

23 South Australian Government 2008; Lawson 2003. 
work team from Outback Services known as the Aboriginal Works Division of SACON. Federal government funding was limited to capital works and administered by SACON.

South Australia was fortunate in its allocation of federal money, receiving more than its per capita share of funds because some states did not take up their allocation. This enabled SACON to move to a planned approach of technology standardisation throughout the communities as an efficiency measure, and to instigate a policy of equal distribution based on service priorities and available funds across many of the communities. The focus at this point became purchasing or designing innovative equipment that could withstand the harsh desert environments and, for the most, part could be repaired by local people in case of breakdown. These two principles became an abiding feature of the service. By the early 1990s most communities had upgraded water infrastructure, but funds did not extend to well planned maintenance services. These continued to be provided on an ad hoc basis in response to major breakdowns, although with increasing experience the SACON team were able to predict community needs and pre-empt major breakdowns through systematic capital works programs. State-funded maintenance budgets arrived with the signing of the initial Bilateral Agreement (between the South Australian and the Commonwealth governments) in 1989. Prior to this time maintenance programs were generally limited to breakdown situations and funded by the federal government through the Department of Aboriginal Affairs.

John Kavanagh, one of the initial technicians and the architect of these services, commenting on the state of former missionary-installed infrastructure (before standardisation) noted:

as the money became available we just looked at the next priority on the list, keeping in the back of our minds all the time that we had to attack problems in a number of communities, rather than just concentrating on one or two. ${ }^{24}$

For the SACON Essential Service Team (EST) the strategy was not just to facilitate maintenance for the number of local private contractors who performed the maintenance work, but to instigate a program that enabled community essential service officers (ESOs), some of whom were Aboriginal people, to handle routine maintenance and breakdown issues themselves without having to always call for outside technical assistance. In many instances this meant that state-of-the-art technology was not always installed; sometimes hardier or simplified technologies were used with the remoteness, arid climate and distance from highly technical services in mind. As Kavanagh noted:

we haven't embraced all the technology that's been available as we were looking for simplicity and something the Essential Service Officers could manage. ${ }^{25}$

24 John Kavanagh pers comm 2008.

25 John Kavanagh pers comm 2008. 


\section{The appropriate technology phase - 1989 to 2000}

In 1989, through the State-Commonwealth Essential Services Agreement (Bilateral Agreement) the Electricity Trust of SA (ETSA), the Engineering and Water Supply Department (EWS) and the federal Labor government through the federal Department of Aboriginal Affairs (DAA) and later under the auspices of the Aboriginal and Torres Strait Islander Commission (ATSIC), agreed to provide matched funding allocations for services to a number of Aboriginal communities. Sixteen communities (Fig 1) came under the Bilateral Agreement in South Australia. These were Amata, Fregon (Kaltjiti), Iwantja (Indulkana) Kalka, Mimili, Pipalyatjara, Pukatja (Ernabella) and Yunyarinyi (Kenmore Park) from the Anangu Pitjantjatjara Yangkuntjatjara (APY) Lands; and the Aboriginal Lands Trust (ALT) communities of Davenport, Gerard, Point Pearce, Koonibba, Nepabunna, Raukkan (Point McLeay), Umoona and Yalata. Umuwa in the APY Lands and Oak Valley the sole community of the Maralinga Tjarutja (MT) Lands were not part of the original agreement, but were included in the revised Bilateral Agreement in 1997. There are of course many more Aboriginal communities in South Australia; however, they were not part of the Bilateral Agreements while ATSIC was operational. The most recent Bilateral Agreement now includes all Aboriginal groups as the Commonwealth moves to transfer full responsibility to the state.

In 1992 the State Labor Government created the Department of State Aboriginal Affairs (DOSAA) transferring the SACON Aboriginal Works Division to DOSAA now called the Essential Services Team (EST) within the portfolio of the Minister for Aboriginal Affairs, Kym Mayes. The Bilateral Agreement was renegotiated in 1997 to become the Agreement for the Provision of Essential Services Infrastructure in Aboriginal Communities in South Australia (the Bilateral Essential Services Infrastructure Agreement). One of the outcomes of this was the formalisation and improvement of funding and partnership arrangements between the state government and the Aboriginal and Torres Strait Islander Commission (ATSIC) which was committed to providing annual grants of not less than \$2.7 million to South Australia for the improvement of essential services infrastructure within Aboriginal communities. The state government also committed to match ATSIC funding which was then channelled into the provision, maintenance, operation and management of essential services infrastructure (water, power and sewerage) to the 18 communities. Funding for essential service infrastructure for communities outside the Bilateral Agreement, such as the many newly developing homelands, remained the direct responsibility of ATSIC, but it was not uncommon for the EST to advise both ATSIC and the community on infrastructure if requested to do so.

The significance of the 1989 Bilateral Agreement was that it provided certainty in funding arrangements over a set period of time although the federal government had provided funds for major capital works since 1979. With the signing of the Bilateral Agreement the states matched these funds. As Kavanagh noted: 
We started to get far more pro-active with maintenance regimes; we had the money now, we could afford to put programs in place. We started looking for specialists that knew how to care for this equipment ... Things started to really, really evolve. ${ }^{26}$

What is impressive about the Department of State Aboriginal Affairs (DOSAA) program is the strategy of installing robust, but simple technology that was standardised across the entire state. This ensured efficiency in responding to breakdowns and allowed the locally based Essential Service Officers to respond to minor breakdowns when they occurred.

DOSAA's programs continued the focus on maintenance and infrastructure standardised across all sites as well as site-specific developments. For example, in terms of broad developments, groundwater monitoring equipment was installed in bores in all communities in order to observe long-term sustainability of aquifers. This represents one example of the pro-active development approach that enabled the prediction of a failing water supply well in advance of the event, thus ensuring the community was not compromised. At the level of individual communities: household meters were installed at Davenport, Nepabunna and Pukutja as there were no data on domestic water use; a reticulation system at Iwantja was replaced; two new bores were installed at Pukutja; and a major upgrade of the rain water storage and treatment compound was constructed at Nepabunna. The team established preventative and routine maintenance schedules across all 16 communities included in these arrangements, resulting in access to good water infrastructure for Aboriginal people in South Australia's remote communities in line with the Australian Drinking Water Standards. ${ }^{27}$

\section{The impact of the National Competition Policy on the work of the Essential Services Team}

Initially, DOSAA project managed many of the contracts funded by ATSIC. The creation of the ATSIC infrastructure programs - Health Infrastructure Priority Projects (HIPP) and the National Aboriginal Health Strategy (NAHS) - resulted in an increase in service provider stakeholders, and the National Competition Policy made it a requirement that the Essential Services Team compete for tenders for projects with other government departments and the private sector. Consequently EST's monopoly on the provision of essential services to remote Aboriginal communities was broken as were the advantages of standardisation. The private companies that tendered for these projects were not in a position to consult with DOSAA as both were competing for the same job, nor was DOSAA able to inform them, or insist on safeguarding standardisation across the communities. Despite this, the essential services team, made up of a small work unit with technical and trade skills and later an engineer, was still responsible for the routine maintenance of infrastructure, including infrastructure installed through private contracts. Commenting on these times Kavanagh noted that:

26 John Kavanagh pers comm 2008.

27 National Health and Medical Research Council 1996. 
where we had tried to put in place uniformity of equipment, it started to fragment, because other organisations came in with different perceptions of how things should be done... ${ }^{28}$

\section{Mainstreaming essential services from 2000 to 2007}

Just prior to the state election in 2002, which saw the Liberals replaced by a Labor government, the EST team moved to regularise the provision of electricity, water and sewerage services on all Aboriginal communities covered under the Bilateral Agreement through the development of a strategic plan that would lead eventually to mainstreaming these services within the portfolios of the state's two major providers: ETSA and SA Water. The rationale for this shift arose out of risk management considerations and a desire to bring Aboriginal communities within a regulatory framework. The immediate motivation for this move arose from two adverse incidents: one on the APY Lands where a child had been electrocuted during a house fire and the Coroner noted the lack of regulatory procedures in Aboriginal communities; the second was the outbreak of E. coli and Campylobacter species at Walkerton in Canada in 2000 where 2300 people became ill and 7 died as a result of a failure in water supply risk management on an Indigenous community. ${ }^{29}$ While the quality of work overseen by DOSAA was later judged to be best-practice by an SA Water audit, ${ }^{30}$ DOSAA knew mainstreaming would prevent duplication of regulatory provision and ensure a robust risk management regime.

DOSAA contracted SA Water to perform all major services because of its strong position as a major public corporation engaged in water supply provision in South Australia with technical and regional capacities for improving water provision to Aboriginal communities. Besides the economies of scale, SA Water had extensive experience in supplying water from various sources including the Murray River, groundwater, dams and reservoirs; experience in transporting water via pipeline networks; access to Community Service Obligation (CSO) funds enabling the provision of water at regulated prices in rural and remote South Australia; established management structures for meter reading, account concessions, connections, disconnections and complaints; expertise in water treatment; previous experience as a direct service provider to Aboriginal communities at Point Pearce and Davenport through the use of bulk meter readings; and experience as maintenance managers of water supply infrastructure in two Aboriginal communities - Raukkan and Gerard. ${ }^{31}$ The last ATSIC contribution of $\$ 4.5$ million was approved for the 2003/2004 financial year.

Initially there was some anxiety amongst Aboriginal leaders that the Department of Aboriginal Affairs and Reconciliation (DAARE) would relinquish

28 John Kavanagh pers comm 2008

29 Hrudey et al 2002.

30 Morgan et al 2003.

31 Department of State Aboriginal Affairs 2002: 27. 
its policy responsibilities to SA Water and in 2004 a small group representing Nganampa Health in the APY Lands, an ATSIC regional councillor and the Aboriginal Health Council formally met with the DAARE Chief Executive, Peter Buckskin to make their views known.

Significantly, SA Water formed a team of specialists to deal with DOSAA's (now formally DAARE) contract, with the head of the unit, Lee Morgan, insisting on an internal structure that would not marginalise Aboriginal issues within SA Water. A natural progression of these developments was the transfer of two of the key technical and engineering staff from the DAARE to SA Water in 2005/2006. This move meant that the detailed corporate knowledge held within DAARE moved across to SA Water with minimal interruption to services for Aboriginal people. While there have been two restructures within DAARE since then it has maintained its project management role, leaving the conduct of work to SA Water and the range of private providers they sub-contract. Meanwhile DAARE shifted its staffing base to policy and project management expertise, but interestingly between 2005 and 2006 re-established its expertise in water engineering along 'with asset and project management, feasibility and conceptual studies, design, documentation and contract supervision'. ${ }^{32}$ This move reflected a realisation that while it no longer provided the technical services, it needed staff with the technical knowledge to make informed decisions on funding and to negotiate with SA Water.

The roll out of the Strategic Plan for electricity initially proceeded with little delay, but eventually stalled along with the transfer of infrastructure services for water supplies. The transfer of water infrastructure was more complex given the need to take account of land ownership and to negotiate with the three Land Holding Authorities: the Aboriginal Lands Trust, the APY Land Council and the Maralinga Tjarutja Trust. What was achieved very quickly was transfer of the provision of infrastructure services to SA Water on an annual contract basis, but the change of government delayed broader consultations with Aboriginal people and to date has not occurred. In the meantime other political events such as the disestablishment of ATSIC, and in 2006 the changes to the Commonwealth Municipal Services funding, known as the MUNS Scheme for town based Aboriginal communities, such as Davenport, Koonibba and Umoona over-took these negotiations. ${ }^{33}$ Internally, DAARE restructured again in 2006 moving from a statutory authority to a unit within Premier and Cabinet and was renamed the Aboriginal Affairs and Reconciliation Division (AARD). This move consolidated Aboriginal Affairs and Reconciliation Division of Premier and Cabinet's role as project manager of essential services with the capacity to broker funds to be outsourced to SA Water and ETSA, but left many questions to do with the impact of the National Water Initiative, user pays, water rights and the renewed focus on conservation and sustainability to be addressed.

32 Willis et al 2004: 24.

33 Parliament of South Australia 2007. 


\section{The National Water Initiative}

In 1994 COAG released its Water Reform Framework which 'recognised that better management of Australia's water resources is a national priority'. ${ }^{34}$ The Water Reform Framework provided the basis for the implementation of the National Water Initiative (NWI) Agreement signed on 25 June 2004. While the deadline for the implementation of the NWI legislation is 2010, there have been numerous intermediate deadlines for various reform objectives since the signing of the agreement. ${ }^{35}$ An underlying theme throughout the NWI is to use water in a sustainable way.

An additional factor of the NWI in relation to domestic water supply is the commitment to the principle of user pays. In short, the NWI Agreement (Clause 65) stipulates consumption based pricing, and full cost recovery and consistency in pricing policies across sectors and jurisdictions. Removal of subsidies (eg, Community Service Obligations) and full cost recovery remain guiding principles and objectives. Resolution of these issues in Aboriginal communities is a new issue confronting the major stakeholders in water supply to Indigenous peoples. This includes their capacity to pay for existing and future services and to engage in the planning processes.

The likely impact of the NWI on Aboriginal communities, AARD and SA Water is three fold. Firstly, responsibility for efficient water use rests with the water service provider and part of the responsibility lies with the community. For example, part of Clause 64 of the NWI Agreement requires the 'efficient delivery of the required services', which makes service providers, such as SA Water, responsible for ensuring that water is delivered 'efficiently'. This might be interpreted as a duty of care to fix leaking pipes and take steps to identify and overcome inefficiencies within the water delivery service so as to minimise wastage. Service providers will be bound by Clause 69 of the NWI Agreement which requires any new works or refurbishments to be ecologically sustainable before they can be implemented. In terms of remote Indigenous communities, this might be interpreted to mean that service providers are not permitted to extract water from bores at a greater rate than the natural recharge rate for the groundwater resources over a sustained period, nor to install new bores where an aquifer is being dewatered, although not all states interpret the legislation this way. This in turn requires the service provider to make these guidelines clear to Aboriginal communities and to provide a service that does not adversely impact on existing supplies.

The requirement to move to full cost recovery for all rural surface and groundwater based systems recognises that while perverse or unintended pricing outcomes are to be avoided, it is acknowledged that some services that are uneconomical might need to be 'maintained to meet social and public health obligations' ${ }^{\prime 6}$ This will be a challenge in the Aboriginal context where AARD

34 Council of Australian Governments 2004.

35 Council of Australian Governments 2004.

36 Council of Australian Governments 2004: Clause 66(v). 
will need to be able to make recommendations to government on the capacity or otherwise of the communities to meet this aim. While the NWI recognises that some communities will never be economically viable, nonetheless it states that in such cases states agree to achieve 'lower bound pricing' in line with commitments to the National Competition Policy (NCP). It is therefore possible that some element of 'lower bound' costs may be introduced into communities that currently do not pay for water. The legislation does, however, state that water pricing will be reviewed 'on a case-by-case basis'. Furthermore, in South Australia the introduction or continuation of a Community Service Obligation (CSO) is permitted.

With reference to the aspiration that water use be ecologically sustainable, there are qualifying phrases that include 'where practical' or 'where feasible'. In terms of the NWI legislation, it appears that Aboriginal communities will have to comply with the legislation and show efficient and sustainable water use. ${ }^{37}$ Much work has been done in this area by agencies other than AARD or SA Water, particularly in the more arid regions of the APY Lands. ${ }^{38}$ The NWI Agreement makes allowance for external environmental impacts such as prolonged drought or climate change that affect the availability of water resources, noting:

As these are outside the influence of the community, but the community may suffer reduced access to water of acceptable quality and quantity as a result of the environmental externalities, such impacts will be recognised and built into the water resource accounting systems in terms of what is available for communities to use in a sustainable way. ${ }^{39}$

Along with this a number of communities have moved to develop their own water management plans that go well beyond sustainability issues to include the way in which water is key to environmental health issues. ${ }^{40}$

Application of the principles of the NWI to Aboriginal communities is further complicated by two other developments. These are the disestablishment of ATSIC and federal government amendments to the Municipal Services Act which moves to mainstream all or most services on those Aboriginal communities that are situated close to large rural towns. Mainstreaming in this sense means that the specific needs of communities will come under the jurisdiction of local government. This includes garbage collection, keeping the neighbourhood tidy and animal control, and puts into question how water, electricity and house rental services will be managed. Most recently this has resulted in five of the communities that sit within the Bilateral Agreement - Davenport, Point Pearce, Umoona, Koonibba, and Raukkan - no longer being designated as remote Aboriginal communities for purposes of funding. This will require resolution of a number of issues. Currently, SA Water or local government delivers water to these five communities to the property gate where it is metered. A single account

37 Council of Australian Governments 2004: Clauses 64 and 69.

38 Dodds et al 2001; Fitzgerald et al 2000.

39 Council of Australian Governments 2004: Clause 82(iii) Part c.

40 Davies et al 2002. 
is dealt with by the local Aboriginal community council levying residents to meet the costs. Under the new arrangements these communities may not be included in the Bilateral Agreement. It is possible that major infrastructure upgrades will become part of SA Water's ordinary business, and individual householders will need to have their meters read on a regular basis in order to receive their account. They will presumably also either pay council rates or local councils will be funded by the federal or state governments for these services. This move assumes standardised mail services, access to houses, street signage and house numbering. A further issue not yet resolved is access to subsidies and concessions. At present Aboriginal residents on communities are not eligible for many concessions as they are not home owners. The land and property are held by one of the land trusts or councils and any move to user pays in line with the NWI will need to resolve these issues. All this excludes the compounding issue of water rights and the looming problem of the sustainability of aquifers in some communities. ${ }^{41}$

\section{Concluding comments}

An audit of water infrastructure on the 18 communities conducted by SA Water in 2004, reported that it was for the most part of a high standard and highly suitable for the environmental context. ${ }^{42}$ In a later report to state government on domestic water supplies to all remote towns in South Australia the service provider DOSAA, was put forward as the state benchmark suitable for all outback towns in South Australia. ${ }^{43}$ The quality of the service provided by the Essential Services team at DOSAA (now restructured as AARD) was partly a result of significant funding, but it was also a result of a highly dedicated and stable team of innovative technicians and engineers who have remained in the sector for over two decades and developed a deep knowledge of both the physical and socio-cultural environment as well as the possibilities for public utilities. With experience spanning several decades one of the engineers and a technician moved on to SA Water shortly after routine maintenance was transferred to SA Water, and one technician moved to FaHCSIA. This ensured a continuity of well planned water services to Aboriginal communities despite the shifts in administrative arrangements. These individuals have maintained their engagement in policy and project management. Commenting on the opportunity to innovate and trial equipment with a freedom not always available to private providers, Kavanagh makes the point:

I think today, we have built such reliability into the equipment, and that's as a result of putting in place good maintenance programs, and when equipment does reach the end of its useful life it's replaced. So, it's that planning component. If you look at the latest SA Water Reports, the checklist appraisals, the emphasis they seem to be promoting is

41 Willis et al 2004.

42 Morgan et al 2003.

43 Keneally 2005. 
water treatment. They are looking to refine. I think they've looked at the infrastructure and said 'well, I don't think there's too much wrong with the basic infrastructure, but there are areas where we can improve the product itself. We're going to raise the bar now, because we're going to look at more of the quality issues. The thing is, we've always stayed within the drinking water guidelines, but they're reasonably broad, the quality is not necessarily as good as it could be. I think the problem is going to be that the funding is not going to come quickly enough. The systems that are being promoted by SA Water, I've no reservations about what's being proposed, but they're going to be expensive. And if it occurs, it's going to take some period of time. ${ }^{44}$

\section{Acknowledgements}

Funding for the various projects mentioned in this paper came from Aboriginal Affairs and Reconciliation Division of Premier and Cabinet, South Australian Government, United Water and the Commonwealth Department of Families, Community Services and Indigenous Affairs. Our thanks are also extended to staff within the Aboriginal Division of SA Water.

\section{References}

Aboriginal Lands Integrated Natural Resource Management Group (ALINRMG) 2003, Integrated National Resource Management Plan for the Aboriginal Lands of South Australia, Adelaide.

Anderson, Robert 1988, Solid Town: The History of Port Augusta, Griffin Press, Adelaide.

Australian Government and House of Representatives 1979, House of Representatives Standing Committee on Aboriginal Affairs, Review into Aboriginal Health (Aboriginal Health 1979), Government Printer, Canberra.

Basedow, Herbert 1906, 'Sources of Central Australian Water Supply', Proceedings of the Adelaide University Scientific Society 1903, SA Government NW Expedition.

Bayley, IAE 1999, 'Review of how Indigenous people managed for water in desert regions of Australia', Journal of the Royal Society of Western Australia 82: $17-25$.

Bureau of Meteorology, 'Australian climates', Australian Government, accessed 15 February 2008: <http//www.bom.gov.au/climate/averages>

44 John Kavanagh pers comm 2008. 
Council of Australian Government (COAG) 2004, 'Intergovernmental Agreement on a National Water Initiative', Australian Government, accessed 12 August 2004: <http://www.coag.gov.au/meetings/250604/index.htm\#nwi>

Davies, A, R Harris, A Kalotas and J Tregenza 2002, The Anangu Pitjantjatjara Yankunytjatjarra Water Management Plan, A report prepared for Anangu Pitjantjatjara Yankunytjatjarra and the Member Communities, Bureau of Rural Sciences, Arid Area Catchment Water Management Board and Aboriginal and Torres Strait Islander Commission, Tony Davies, Adelaide.

Department of State Aboriginal Affairs (DOSAA), 2002, Strategic Plan for Essential Service Delivery, Division of State Aboriginal Affairs (DOSAA), Adelaide.

Dodds, AR, SD Hostetler, and G Jacobson 2001, Kapi Nganampa: Community Water Supplies in the Anangu Pitjantjatjara Lands, South Australia: Sustainability of Groundwater Resources, Bureau of Rural Sciences, Canberra.

Fitzgerald, Jim, D Cunliffe, S Rainow, S Dodds, S Hostetler, and G Jacobson 2000, Groundwater Quality and Environmental Health Implications: Anangu Pitjantjatjara Lands, South Australia, Bureau of Rural Sciences, Canberra.

Giles, Ernest 1889, Australia Twice Traversed, Sampson Low, Marston, Searle and Rivington, London.

Hrudey, S, P Huck, R Payment, R Gillham and E Hrudey 2002, ‘Walkerton: Lessons learned in comparison with waterborne outbreaks in the developed world', Journal of Environmental Engineering Science 19: 397-407.

Indigenous Studies Program, Agreements, Treaties and Negotiated Settlements Project (ATNS) 2006, Overarching agreement on Indigenous Affairs between the Commonwealth of Australia and the State of South Australia, The University of Melbourne, accessed 10 November 2009: <http://www.atns.net.au/ agreement.asp?EntityID=3343>

Keneally, G 2005, The Outback Water Supplies Discussion Paper - a Report by the Working Group for Outback Water Supplies, Government of South Australia, Adelaide.

Lawson, R 2003, 'The Pitjantjatjara Land Rights Act 1981', Bennelong Society Conference 2003, An Indigenous Future? Challenges and Opportunities, accessed 21 October 2008: <http://www.bennelong.com.au/conferences/ conference2003/Lawson2003.php>

Magarey, AT 1899, 'Aborigines' water-quest', Proceedings of the Royal Geographical Society of Australasia (South Australian Branch) 3: 67-82. 
Mattingley, Christobel and Ken Hampton 1988, Survival in Our Own Land: 'Aboriginal' 'Experiences' in South Australia since 1836 Told by Nungas and Others, Wakefield Press, Adelaide.

Morgan, L, D Venema and C Pelekani 2003, Water Quality and Quantity Appraisal for Remote Aboriginal Communities for Water Service Improvement, SA Water, Adelaide.

National Health and Medical Research Council, 1996, Australian Drinking Water Guidelines, Commonwealth of Australia, Canberra.

Parliament of South Australia 2007, 'Inquiry into the impact of the Australian government changes to municipal services funding upon four Aboriginal communities in South Australia', 4th Report to the Aboriginal Lands Parliamentary Standing Committee, 25 July 2007, 51st Parliament, Adelaide, viewed 11December 2009: <http:/ / www.parliament.sa.gov.au/Committees/ Standing/LC/AboriginalLandsParliamentaryStandingCommittee/TabledR eports/4thReportMunicipalServicesFundingInquiry.htm>

Pearce, Meryl, Eileen Willis, Carmel McCarthy, Fiona Ryan and Ben Wadham 2008, A Response to the National Water Initiative from Nepabunna, Yarilena, Scotdesco and Davenport Aboriginal Settlements, DKCRC Research Report 36, Desert Knowledge Cooperative Research Centre, Alice Springs.

South Australian Government, 'Documenting democracy: Pitjantjatjara Land Rights Act 1981 (SA)', accessed 21 October 2008: <http:/ / www.foundingdocs. gov.au/item.asp?sdID=46\#history>

Tindale, Norman Barnett 1974, Aboriginal Tribes of Australia, Australian National University Press, Canberra.

Toussaint, Sandy, Patrick Sullivan and Sarah Yu 2005, 'Water ways in Aboriginal Australia: an interconnected analysis', Anthropological Forum 15: 61-74.

Willis, Eileen, Meryl Pearce, Tom Jenkin and Simon Wurst 2004, Water Supply and Use in Aboriginal Communities in South Australia, Worldwide Online Printing, Adelaide. 